\title{
Key to Common Bay Trees of Florida'
}

\author{
Lynn Proenza and Michael Andreu²
}

\section{Introduction}

Bay trees in Florida can be difficult to distinguish because their leaves all look alike at first glance. The leaves of bays are all simple, large, elliptical, and evergreen. In addition, several bay species grow in overlapping ranges and habitats. Many times two or more different species of bay will be found growing right next to one other.

One simple way to distinguish these woody plants is by focusing on their distinctive flowers and fruits. However, these features are not present throughout the year, so it is helpful to learn about other bay characteristics in order to help you decide which species you are looking at in every season of the year. Fortunately, each bay species has at least one characteristic that makes it distinguishable from similar trees of other species. In some cases, site, or where the plant is found on the landscape, can be helpful. For instance, Magnolia grandiflora (southern magnolia, bull bay) and Persea borbonia (red bay) are more commonly found in uplands, whereas Gordonia lasianthus (loblolly bay), Magnolia virginiana (sweetbay), and Persea palustris (swamp bay) are typically wetland dwellers. Morphological features can also be of use. For example, $M$. virginiana and $P$. borbonia have glaucous (bluish-gray) lower leaf surfaces, but the others do not. The difference between these two species is the stipule scars that completely surround the twig in M. virginiana. Once you learn the key features or group of features that are characteristic to a species, identification is relatively easy.

Florida contains many different plant communities (habitats) in which bay species occur. Descriptions of these natural plant communities are found in the Guide to the Natural Communities of Florida, 2010 edition, created by the Florida Natural Areas Inventory (FNAI).

This fact sheet was produced to help in the identification of common bay trees found in Florida by using the dichotomous key below. This key focuses on those features that are present year round. Following the key, a basic description, along with photographs, of each species is given to help with the identification process.

The species included in this fact sheet are:

- Gordonia lasianthus; loblolly bay

- Magnolia grandiflora; southern magnolia, bull bay

- Magnolia virginiana; sweetbay

- Persea borbonia; red bay

- Persea palustris; swamp bay

1. This document is FOR311, one of a series of the School of Forest Resources and Conservation, Florida Cooperative Extension Service, Institute of Food and Agricultural Sciences, University of Florida. Original publication date September 2013. Visit the EDIS website at http://edis.ifas.ufl.edu.

2. Lynn Proenza, graduate student, School of Forest Resources and Conservation; and Michael Andreu, associate professor, School of Forest Resources and Conservation; University of Florida, Gainesville, Florida 32611. 


\section{Key}

1a Stipular scars encircle the twig

2a Leaves large, thick, leathery; underside of leaves sometimes with rusty pubescence especially on younger growth; not fragrant when crushed

$2 b$ Leaves thin; underside of leaves glaucous; fragrant when crushed

1 b Stipular scars, if any, do not encircle the twig

$\begin{array}{ll}\text { 3a Leaf margins serrated } & \text { 1.Gordonia } \\ \text { from apex to base. Leaves not } & \text { lasianthus } \\ \text { aromatic when crushed } & \end{array}$

3b Leaf margins entire; leaves aromatic when crushed; often covered with insect galls

4a Lower leaf $\quad$ 5. Persea palustris
surfaces with
shaggy brown
pubescence,
$\begin{aligned} & \text { especially along } \\ & \text { principle veins }\end{aligned}$
$\begin{aligned} & \text { 4b Lower } \\ & \text { leaf surfaces }\end{aligned}$
glaucous
with gold
$\begin{aligned} & \text { pubescence borbonia } \\ & \text { (magnification }\end{aligned}$
required)

\section{Plant Descriptions}

\section{Gordonia lasianthus; loblolly bay}

Habitat type: Wetlands, bay swamps, bogs.

Form: Evergreen, although shedding of some leaves during fall and winter is common. Small to medium tree up to 20 $\mathrm{m}$ tall.

Bark and twigs: Bark narrowly furrowed, ridges flat, thick, gray to dark gray.

Leaves: Alternate. Up to $16 \mathrm{~cm}$ long, $5 \mathrm{~cm}$ wide. Glabrous upper surface, dull green lower surface. Margins serrated. Some leaves turn red in fall and winter before dropping off.

Flowers: Late spring to summer. White, cup-shaped, 5 -petaled to $8 \mathrm{~cm}$ in diameter, stalks to $8 \mathrm{~cm}$ long. Many yellow stamens.
Fruit: Woody capsule to $1.5 \mathrm{~cm}$ long with $4-8$ winged seeds up to $1 \mathrm{~cm}$ long, matures in early fall.

Distinguishing characteristics: The bark has narrow, furrowed ridges that are flat. The margins are serrated, whereas the margins on other bay trees are entire.

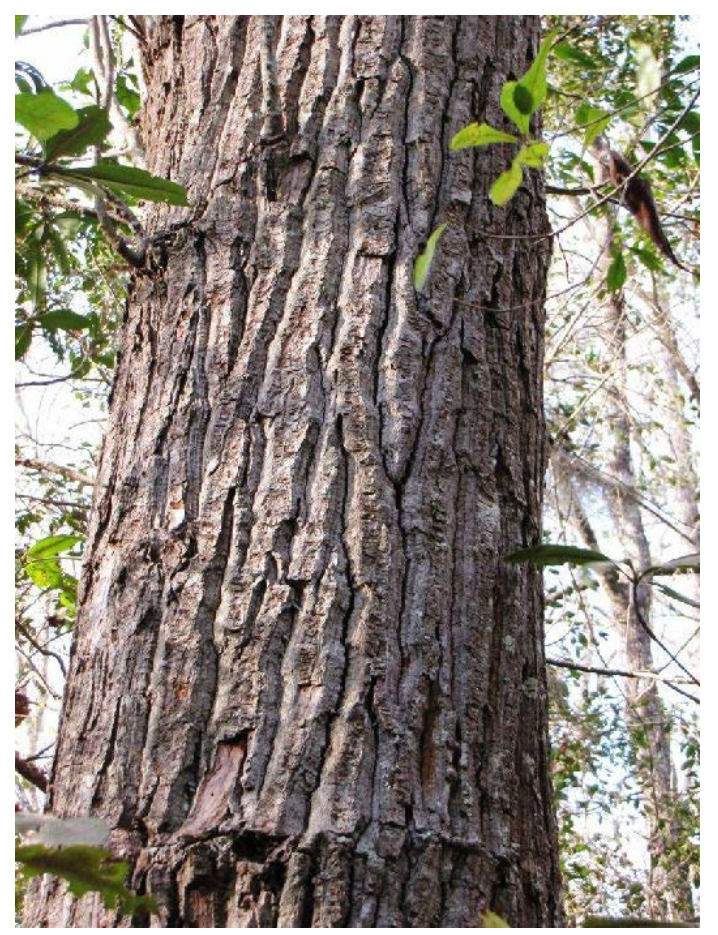

Figure 1. The bark of Gordonia lasianthus is a distinct characteristic. Credits: Lynn Proenza

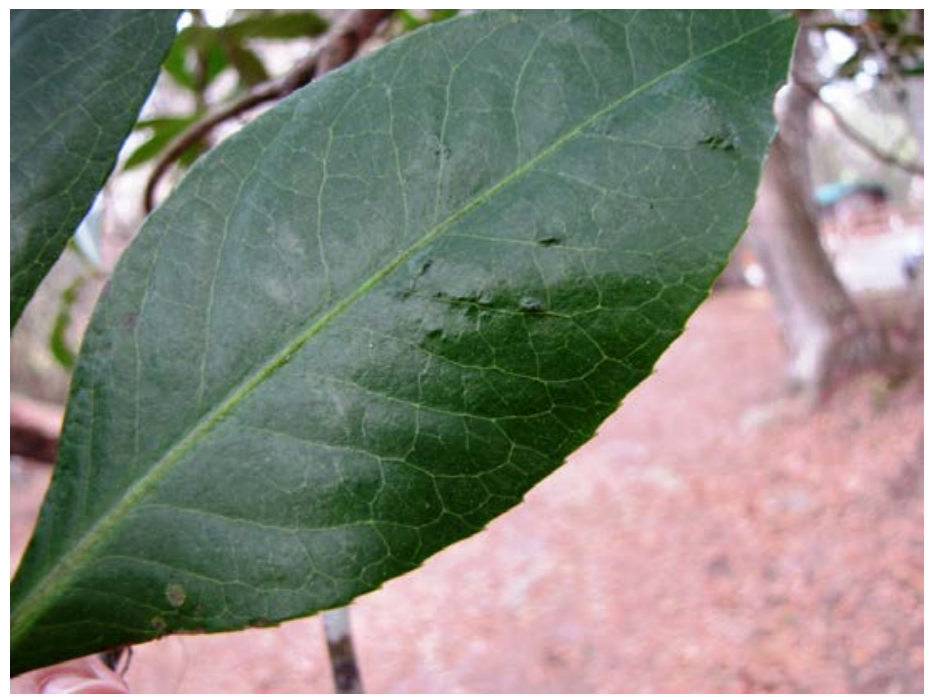

Figure 2. The leaf margins of Gordonia lasianthus are serrated. Credits: Lynn Proenza 


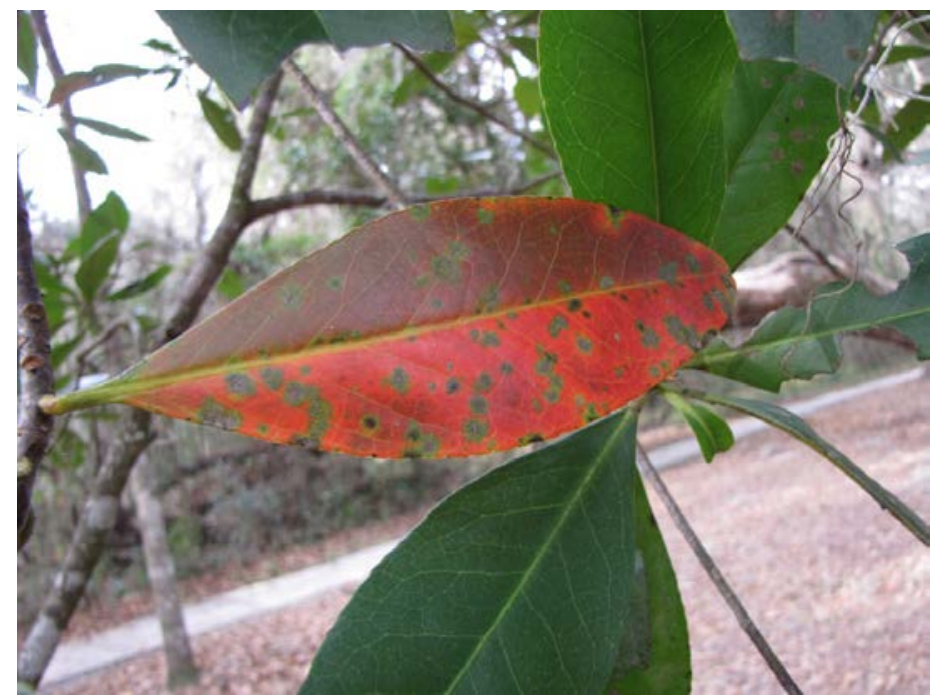

Figure 3. Although evergreen, some of the leaves on Gordonia lasianthus will turn red in the fall and winter before dropping off. Credits: Lynn Proenza

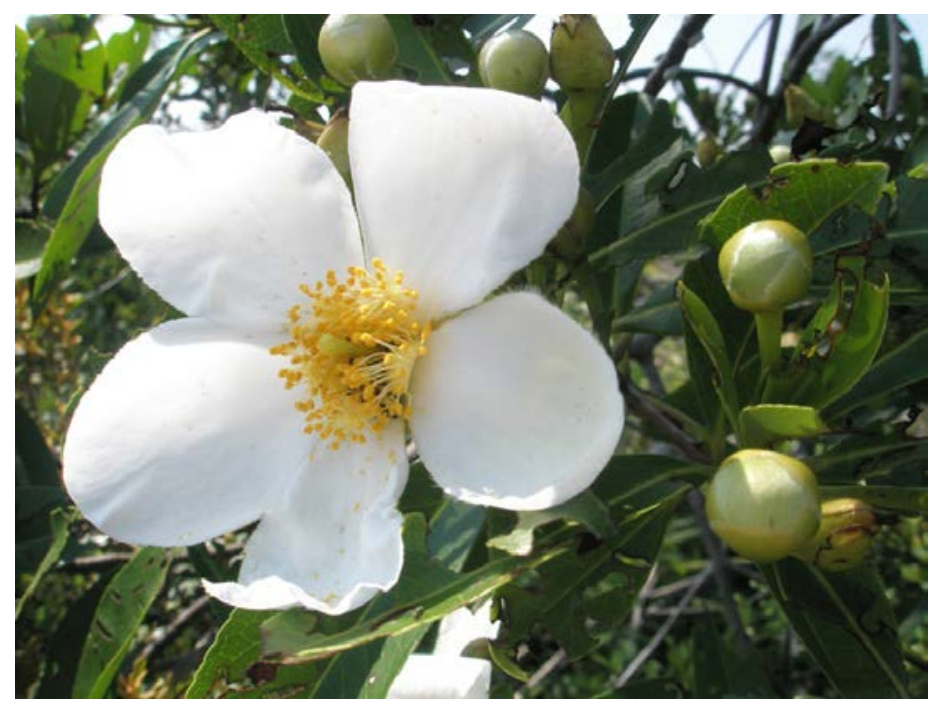

Figure 4. The flower of Gordonia lasianthus is cup-shaped and 5-petaled.

Credits: Lynn Proenza

\section{Magnolia grandiflora; southern magnolia, bull bay}

Habitat type: Well-drained upland woodlands, bluffs, coastal hammocks, mesic woodlands, ravines.

Form: Evergreen. Medium to large tree that typically grows 25 to $30 \mathrm{~m}$ tall but occasionally can reach up to $40 \mathrm{~m}$ tall.

Bark and twigs: Bark smooth when young; mature trees have large, scaly gray plates. Twigs with rusty pubescence on newer growth that turns darker brown and sloughs with age. Stipular scars evident and encircle the twig.

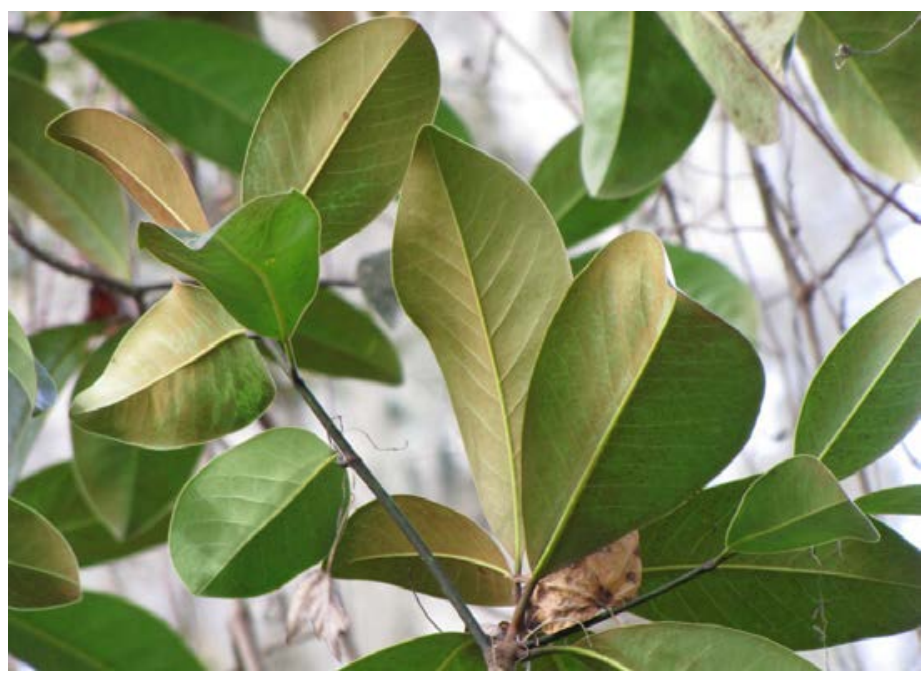

Figure 5. The leaves of Magnolia grandiflora are shiny and glabrous on the upper surface, and have varying amounts of rusty pubescence on the lower surface.

Credits: Lynn Proenza

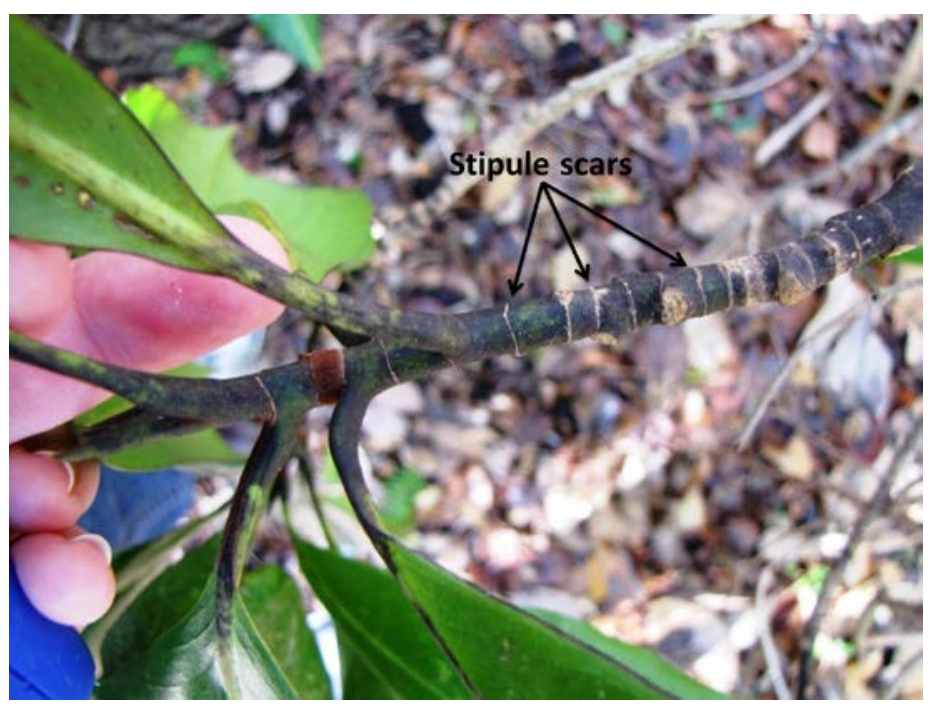

Figure 6. Stipule scars (appearing as white lines on this twig) surround the twigs of both Magnolia species covered in this fact sheet Credits: Lynn Proenza

Leaves: Alternate. Leathery and thick up to $30 \mathrm{~cm}$ long, $10 \mathrm{~cm}$ wide. Upper surface waxy, glabrous, shiny, and dark green. Lower surface sometimes with dense rusty pubescence, sloughing with age, otherwise paler green and glabrous. Horticultural varieties are bred to have a darker green upper leaf surface and more pronounced rusty pubescent lower leaf surface than you will see in naturally occurring trees (Figure 9).

Flowers: Spring to summer. White, fragrant, saucer-shaped, large, to $20 \mathrm{~cm}$ in diameter. 
Fruit: An aggregate of follicles that together appear cone-like. To $10 \mathrm{~cm}$ long, turning reddish brown with age. Pubescent, with shiny red seeds attached by a thin, hair-like fiber. Appearing in late summer.

Distinguishing characteristics: Stipule scars completely encircle the twig, a characteristic for all species in the Magnoliaceae family. The leaves of Magnolia grandiflora are thick and leathery, whereas Magnolia virginiana leaves are thin, papery, and fragrant. The lower leaf surface of Magnolia grandiflora is sometimes rusty pubescent or green and glabrous, whereas the lower leaf surface of Magnolia virginiana is glaucous.

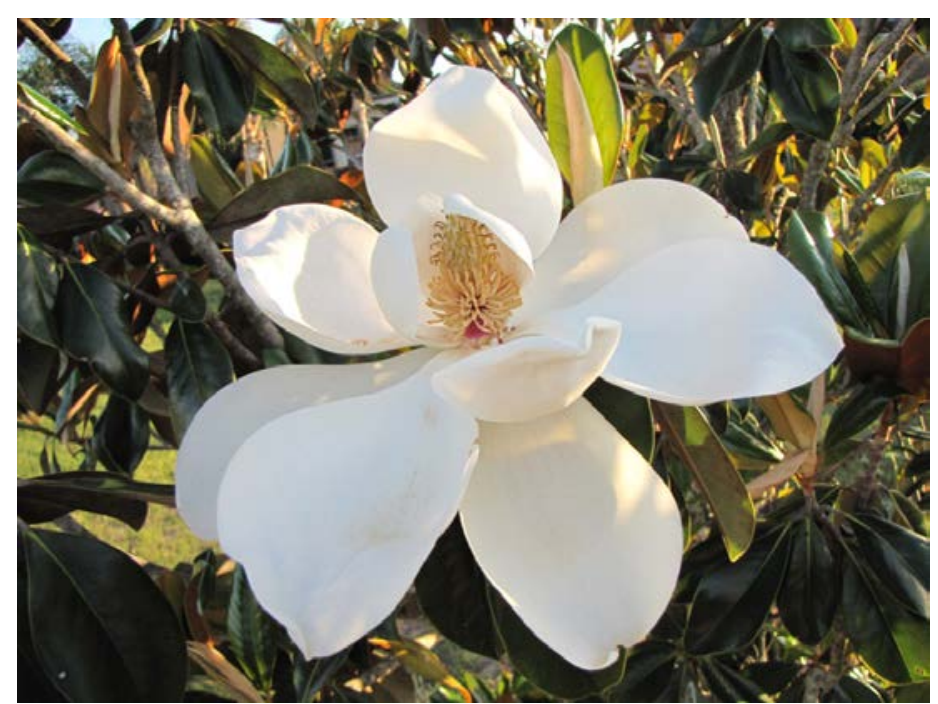

Figure 7. The flowers on Magnolia grandiflora are large, white, fragrant, and very showy.

Credits: Lynn Proenza

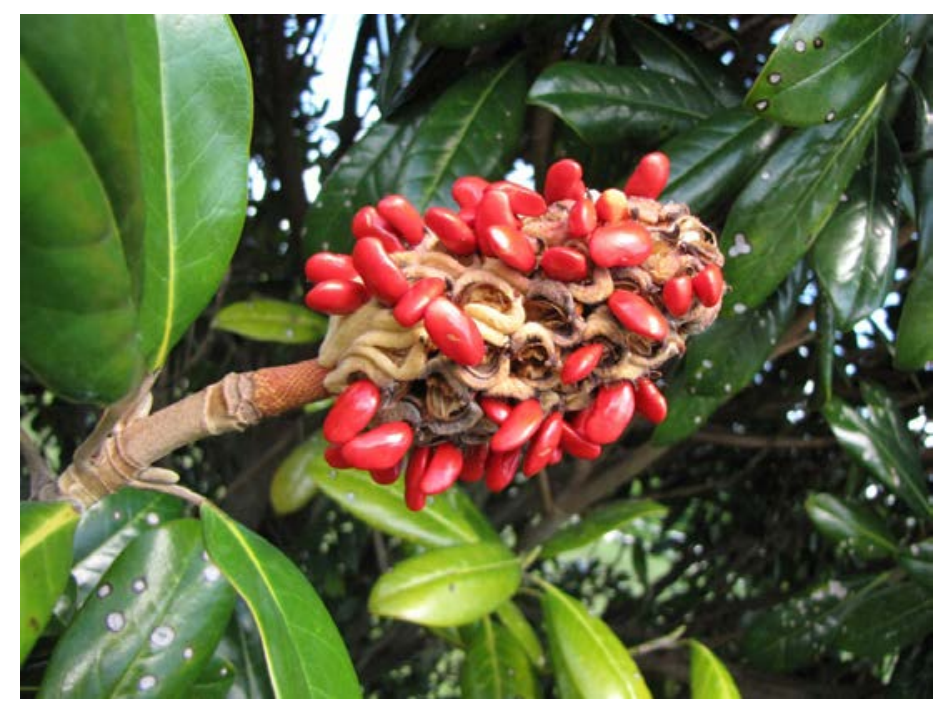

Figure 8. Magnolia grandiflora fruit is large, pubescent, and cone-like with shiny red seeds.

Credits: Lynn Proenza

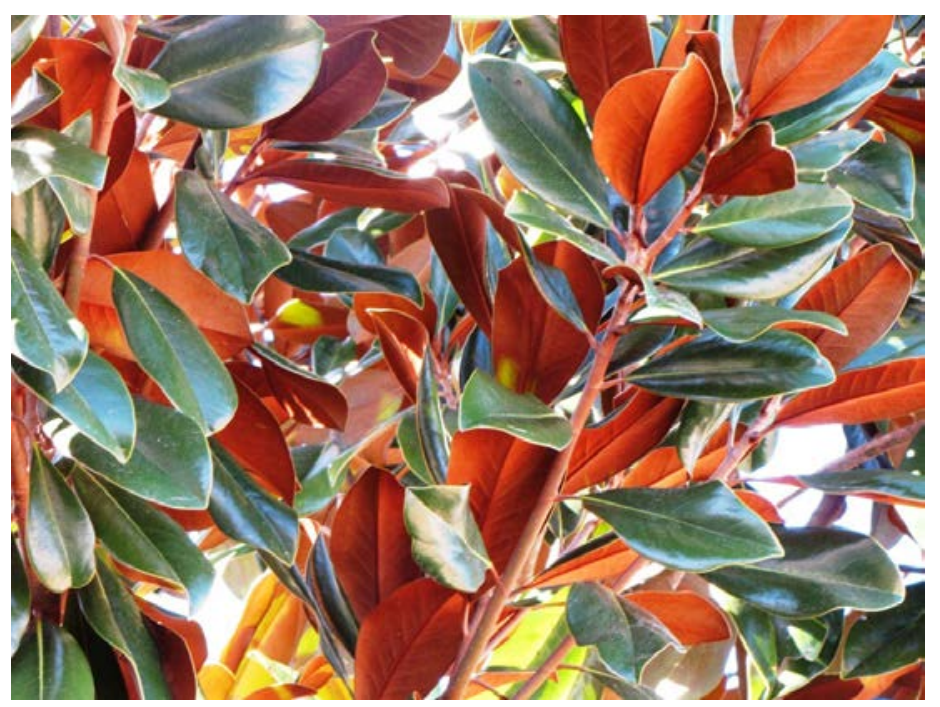

Figure 9. The leaf characteristics for the horticultural varieties of Magnolia grandiflora are more pronounced than leaf characteristics for naturally occurring trees.

Credits: Lynn Proenza

\section{Magnolia virginiana; sweetbay}

Habitat type: Wetlands, bay swamps, creek bottoms, bogs, wet flatwoods.

Form: Evergreen. Medium to large tree to about $30 \mathrm{~m}$ tall.

Bark and twigs: Smooth, dark gray bark. Twigs with silvery pubescence on newer growth, sloughing with age. Stipular scars evident and encircle the twig.

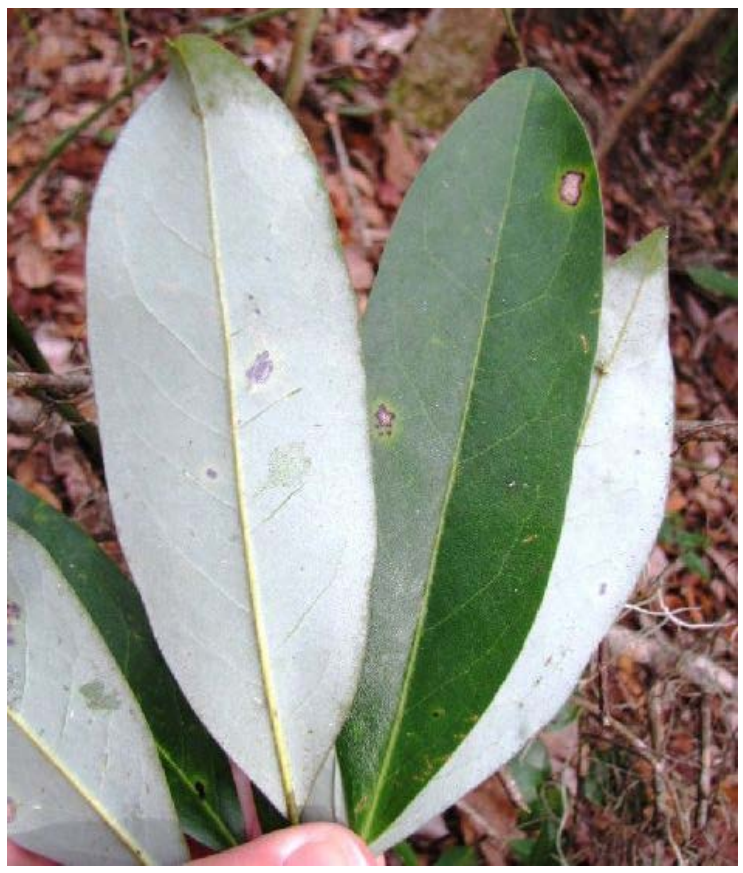

Figure 10. The lower surface of the leaf of Magnolia virginiana is glaucous.

Credits: Lynn Proenza 
Leaves: Alternate. Up to $15 \mathrm{~cm}$ long, $6 \mathrm{~cm}$ wide. Aromatic when crushed. Upper surface dull green and glabrous. Lower surface glaucous with silky pubescence.

Flowers: Summer to fall. White, to $7 \mathrm{~cm}$ in diameter, showy, fragrant. Similar to Magnolia grandiflora (see Figure 7).

Fruit: An aggregate of follicles that together appear conelike. To $5 \mathrm{~cm}$ long. Glabrous, turning reddish brown with age. Matures in late summer. Shiny red seeds attached by a thin, hair-like fiber. Similar to Magnolia grandiflora (see Figure 8).

Distinguishing characteristics: Stipule scars completely encircle the twig, a characteristic for all species in the Magnoliaceae family. The leaves of Magnolia virginiana are aromatic when crushed and are thin and papery, whereas Magnolia grandiflora are thick and leathery. The lower leaf surface of Magnolia virginiana is glaucous, whereas the lower leaf surface of Magnolia grandiflora is sometimes rusty pubescent or paler green and glabrous.

\section{Persea borbonia; red bay}

Habitat type: Xeric to mesic woodlands, scrub.

Form: Evergreen. Small to medium tree to $20 \mathrm{~m}$ tall.

Bark and twigs: Bark fissured, dark reddish-brown. Twigs with gold pubescence.

Leaves: Alternate. Up to $15 \mathrm{~cm}$ long, $6 \mathrm{~cm}$ wide. Upper surface glabrous, lower surface glaucous, gold pubescence is appressed (the tiny hairs grow very close to the surface of the leaf). Magnification is required to see pubescence. Aromatic when crushed. Often deformed by leaf gall insects.

Flowers: Spring to summer. Greenish, small clusters on long stalk, borne in axils of leaves.

Fruit: Drupe. Round, dark blue to black when mature in fall.

Distinguishing characteristics: The leaves of this species are aromatic when they are crushed, which is characteristic of the Lauraceae family. Persea palustris is also aromatic but has shaggy brown pubescence on the lower surface of the leaves and twigs, whereas Persea borbonia has a glaucous lower surface.

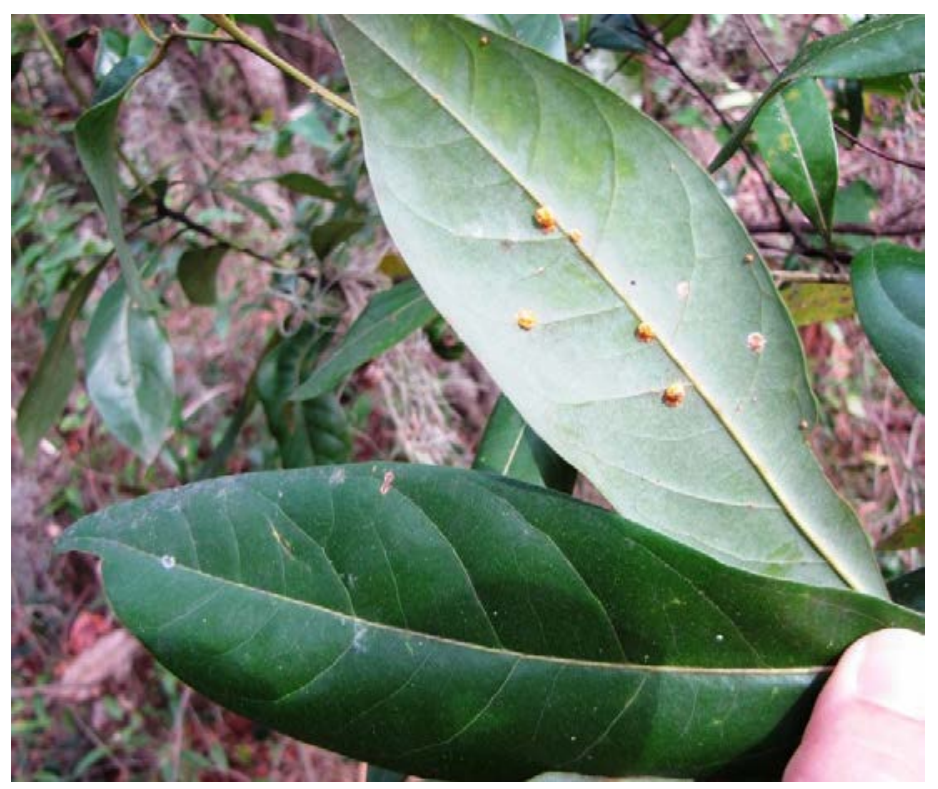

Figure 11. The lower surface of the leaf on Persea borbonia is glaucous with some gold pubescence, and the upper surface is glossy. Credits: Lynn Proenza

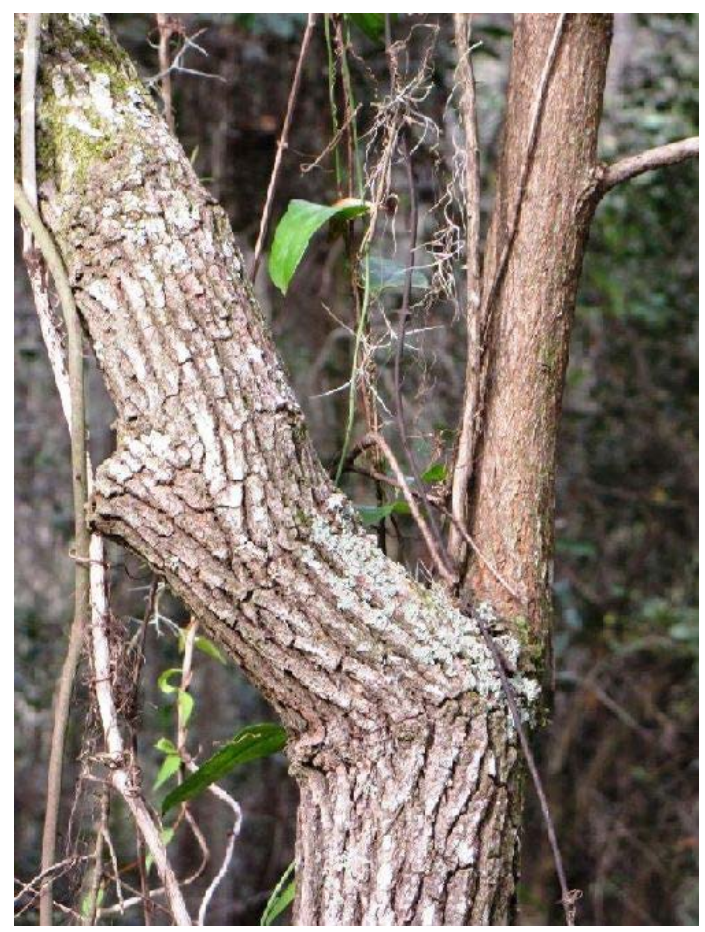

Figure 12. This photo shows both older (left) and younger (right) bark of Persea borbonia.

Credits: Lynn Proenza

Note: Persea borbonia is currently experiencing a decrease in abundance due to a non-native Asian ambrosia beetle which causes laurel wilt disease; in sites where laurel wilt disease infestation is severe, you will likely see only dead trees. The wilted leaves of Persea borbonia usually persist on the tree after it dies (Figure 13). 


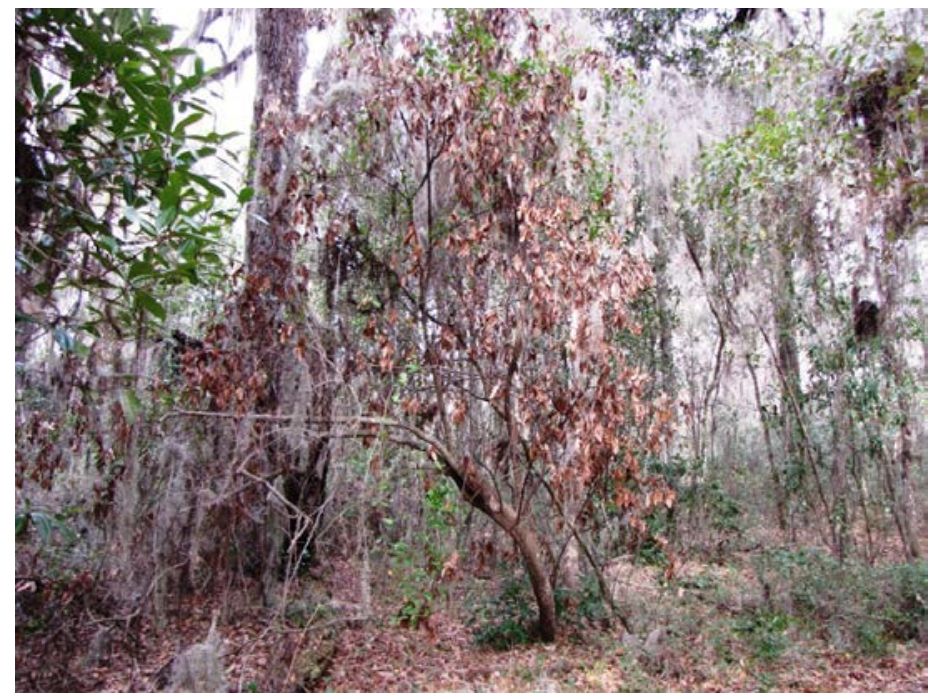

Figure 13. Persea borbonia is now typically found dead due to the non-native Asian ambrosia beetle.

Credits: Lynn Proenza

\section{Persea palustris; swamp bay}

Habitat type: Wetlands, swamps, wet pinewoods, maritime forests, savannas, marshes.

Form: Evergreen. Small tree to $12 \mathrm{~m}$ tall.

Bark and twigs: Bark fissured, brown. Twigs with dense pubescence sloughing with age, then turning dark brown.

Leaves: Alternate. Up to $20 \mathrm{~cm}$ long, $5 \mathrm{~cm}$ wide. Upper surface with some pubescence when young, sloughing with age. Lower surface with shaggy brown pubescence, especially along principle veins, which can feel fuzzy to the touch. Petioles are also pubescent. Aromatic when crushed. Often deformed by leaf gall insects.

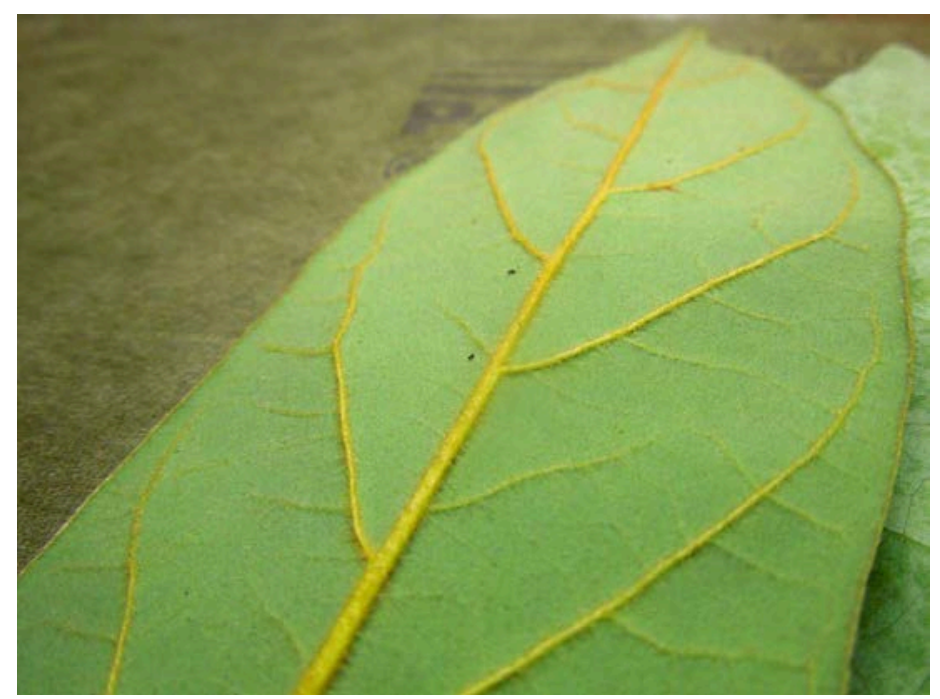

Figure 14. The lower surface of the leaf on the Persea palustris has shaggy brown hairs that feel fuzzy to the touch.

Credits: Paul Proctor
Flowers: Spring to summer. Greenish-white, small clusters on long stalks, borne in leaf axils.

Fruit: Drupe. Oblong to $1 \mathrm{~cm}$ long. Dark-blue to black when mature in fall.

Distinguishing characteristics: The leaves of this species are aromatic when they are crushed, which is characteristic of the Lauraceae family. Persea borbonia is also aromatic, but it has a glaucous coating on the lower surface of the leaves, whereas Persea palustris has shaggy brown pubescence on the lower surface of the leaves and twigs.

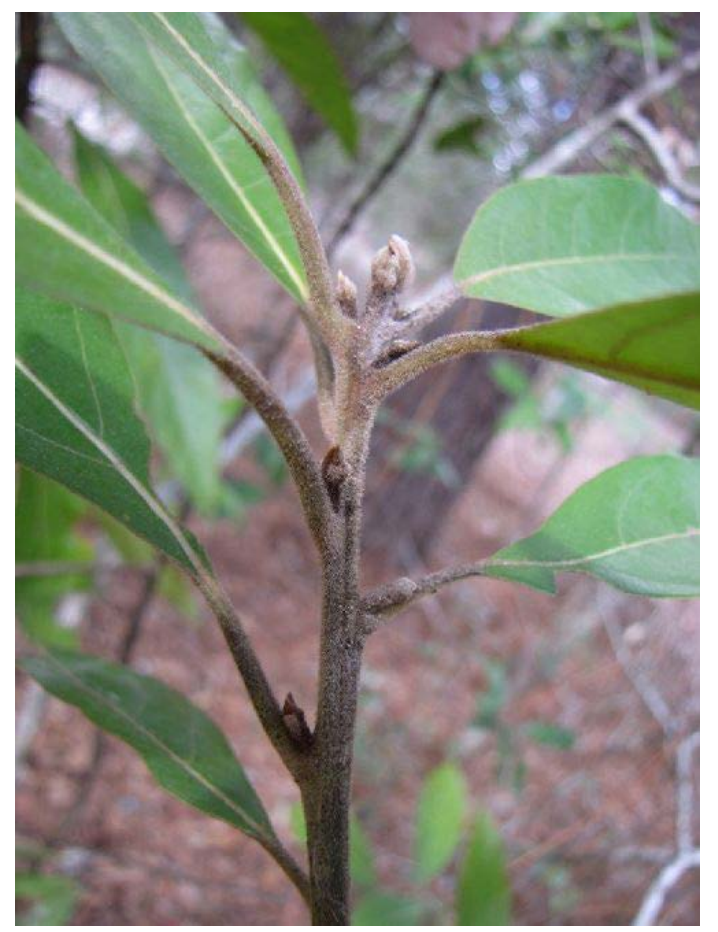

Figure 15. Younger twigs of Persea palustris are covered in brown, dense hairs.

Credits: Lynn Proenza 


\section{References and Additional}

\section{Resources}

Cook, Will. 2011. Trees, Shrubs, and Woody Vines of North Carolina [online]. Duke University. Accessed: January 19, 2012. Available: http://www.duke.edu/ cwcook/trees/

eFloras. 2008. Published on the Internet http://www.efloras. org [accessed July 11, 2011 - August 22, 2011]. Missouri Botanical Garden, St. Louis, MO \& Harvard University Herbaria, Cambridge, MA.

Godfrey, Robert K. 1988. Trees, Shrubs, and Woody Vines of Northern Florida and Adjacent Georgia and Alabama. Athens, Georgia: University of Georgia Press.

Hall, David W. 1993. Illustrated Plants of Florida and the Coastal Plain. Maupin House, Gainesville, Florida.

Nelson, Gil. 1994. The Trees of Florida. Sarasota, Florida: Pineapple Press Inc.

Van Deelen, Timothy R. 1991. "Persea borbonia." In: Fire Effects Information System, [Online]. U.S. Department of Agriculture, Forest Service, Rocky Mountain Research Station, Fire Sciences Laboratory (Producer). Available: http://www.fs.fed.us/database/feis/ [2012, January 19]. 